\title{
DIRTY JEW-DIRTY MEXICAN: DENVER'S 1949 LAKE JUNIOR HIGH SCHOOL GANG BATTLE AND JEWISH RACIAL IDENTITY IN COLORADO
}

\author{
Michael Lee \\ University of Colorado at Boulder
}

On the morning of Saturday, October 1, 1949 Denver's Jewish and Mexican-American parents woke up, ate breakfast, and read in their newspapers that dozens of their children had been engaged in a racebased gang battle just the day before. Though historians have largely ignored this event, the Jewish response to it, especially through the local chapter of the Anti-Defamation League of B'nai B'rith and its involvement in an interracial neighborhood council, demonstrated how Jewish racial identity was in part informed by the curious racial geography of the West - a racial geography that was too often shaped by contrast with Mexicans. ${ }^{1}$ This episode as well as a few notable instances of anti-Semitism, including the 1905 lynching of Jacob Weisskind, suggest a more nuanced story than the received wisdom about Jews being "at home" in Denver. ${ }^{2}$ Indeed, some historians who have written on Jews in the West

1 This event was briefly mentioned by lawyer and historian Tom I. Romero in "Our Selma is Here: The Political and Legal Struggle for Educational Equality in Denver, Colorado, and Multiracial Conundrums in American Jurisprudence," Seattle Journal for Social Justice (Fall/Winter 2004), 78. However, Romero was primarily interested in the Chicano perspective, and did not view the incident from the perspective of Jews' racial identity. Whenever practicable or to make a broader historical point, I do not alter the terms by which historical actors in the sources refer to themselves or to other ethnic groups. This also shows an evolution in how ethnic groups perceive themselves and others. However, for material outside of quotes, and for the sake of continuity and clarity, I refer to Jewish Americans mainly as "Jews"; those of Mexican heritage living in the United States as "Mexicans," "Chicanos," or "Mexican Americans"; and Gentile whites as "Anglos."

2 The quoted phrase is from Deborah Dash Moore, At Home in America: Second Generation New York Jews (New York: Columbia University Press, 1981). For optimistic accounts of Jews in Denver and Colorado that portray a confident Jewish population see Jeanne Abrams, Dr. Charles Spivak: A Jewish Immigrant and the American Tuberculosis Movement (University Press of Colorado, 2009); Allen duPont Breck, The Centennial History of the Jews of Colorado, 1859-1959 (Denver: The Hirschfield Press, 1960); and Ida Uchill, Pioneers, Peddlers, and Tsadikim (Denver: Sage Books, 1957; reprint, Boulder: University Press of Colorado, 2000). Page citations are to the reprint edition. To be fair, however, Uchill does have a nine-page chapter in her over three hundred page book that does at least describe anti-Semitism in Denver. But it is antiquarian in nature and a detour in a larger narrative of progress, success and eventual acceptance. Moreover, Uchill asserts that social anti-Semitism was of no concern to most Jews in the city and totally omits the racial strife between Jews and Mexicans on the West Side of Denver. 
have argued that one of the primary reasons why the region was different from the East was because anti-Semitism was relatively absent and subdued. ${ }^{3}$ Although this might hold true for some western cities, this was not the case in Denver, where it was present and at times extremely overt. Furthermore, anti-Semitism, coupled with a pronounced anti-Mexican sentiment among the broader Anglo community, proved important in the formation of Jewish racial identity.

More broadly, however, such a case study is worthy of careful scholarly consideration precisely because it does focus on Jewish-Mexican interaction, rather than Jewish-black interaction. Without a doubt, the literature regarding Jewish-black interaction is rich, with many decades of fruitful and careful scholarship behind it. ${ }^{4}$ On the other hand, the study of Jewish-Mexican interaction in the West, and on a more general level, Jewish-Latino interactions in the United States, has received comparatively little attention from professional historians. In fact, the only notable exception to this trend has been George J. Sánchez's optimistic treatment of the Boyle Heights neighborhood of Los Angeles during the Cold War. In this article length study titled, " 'What's Good for Boyle Heights is Good for the Jews': Creating Multiculturalism on the Eastside During the 1950s," Sánchez examined the social and political collaboration between a small group of Jews and Mexican Americans, and the positive impact that relationship had on "civil rights" and "radical multiculturalism" in the neighborhood. ${ }^{5}$ Indeed, it has only been in recent years that trailblazing historians like Ellen Eisenberg have begun to write book length studies on the often complex and contradictory relationships between Jews and other racial groups in the West. ${ }^{6}$ More to the point,

3 John Livingston, "Introduction," in Jews of the American West, eds. John Livingston and Moses Rischin (Detroit: Wayne State University Press, 1991), 21; Jeanne Abrams, Jewish Women Pioneering the Frontier Trail (New York: New York University Press, 2006), 11.

4 See Cheryl Lynn Greenberg, Troubling the Waters: Black-Jewish Relations in the American Century (Princeton: Princeton University Press, 2006); Eric J. Sundquest, Strangers in the Land: Blacks, Jews, Post Holocaust America (Cambridge, Mass: The Belknap Press of Harvard University Press, 2005); Jack Saltzman and Cornel West, eds., Struggles in the Promised Land: Toward a History of Black-Jewish Relations in the United States (New York: Oxford University Press, 1997); and Murray Friedman, What Went Wrong? The Creation and Collapse of the Black-Jewish Alliance (New York: The Free Press, 1995).

5 George J. Sánchez, “'What's Good for Boyle Heights is Good for the Jews': Creating Multiculturalism on the Eastside During the 1950s," American Quarterly 56: 3 (September 2004), 634. Studies diverging from the black-Jewish paradigm and focusing on a multiethnic approach to the West include Allison Varzally, Making a Non-White America: Californians Coloring Outside Ethnic Lines, 1925-1950 (Berkeley: University of California Press, 2008); Mark Wild, Street Meeting: Multiethnic Neighborhoods in Early Twentieth-Century Los Angeles (Berkeley: University of California Press, 2005); and Shana Bernstein, "Building Bridges at Home in a Time of Global Conflict: Interracial Cooperation and the Fight for Civil Rights in Los Angeles, 1933-1954," Ph.D diss., Stanford University, 2003.

6 Ellen Eisenberg, The First to Cry Down Injustice? Western Jews and Japanese Removal During WWII (Lanham, MD: Lexington Books, 2008). 
however, the story of Jewish-Mexican interaction is significant and worthy of study because it is a story that can only be best told and understood in the context of the American West; simply put, place does matter, especially when it comes to American Jewish history.

\section{The Geography of Ethnicity on Denver's West Side}

Following Colfax Avenue due west toward the majestic Rocky Mountains, Denver's Jewish West Side once stretched from the banks of the South Platte River to Jefferson County's border. For decades, synagogues, Jewish agencies, and businesses were common in this section of the city and catered to a population that was predominantly eastern European in heritage. In fact, by the early 1950s-the height of Jewish cultural influence in this area-institutions like the Hebrew Educational Alliance, Beth Israel Home and Hospital, the Jewish Consumptives Relief Society (later renamed the American Medical Center), and the Guldman Community Center stood as unquestionable proof of just how Jewish this part of Denver had become.

The nucleus of this community was established in the late nineteenth century from the remnants of a failed agricultural colony in Cotopaxi, Colorado. Fleeing pogroms, boycotts and the draconian dictates of Czar Alexander III, over two million Jews left the Russian Empire for a better life somewhere else. Most of these refugees found their way to the eastern shores of the United States. However, urban centers like New York City soon became breeding grounds for diseases that included tuberculosis - otherwise known as the "white plague." Due to this and other reasons, Jewish relief agencies like the Hebrew Immigrant Aid Society (HIAS) endeavored to resettle a number of these Russian Jews in less crowded and seemingly more healthful parts of the country. One of these alternatives was the small mining town of Cotopaxi. ${ }^{7}$

Situated in a valley near the banks of the Arkansas River, Cotopaxi was an excellent location for mining, but not for agriculture; in fact, poor soils, freezing temperatures and flooding characterized the nature of the region. Unaware of this at the time, and deceived by smooth-talking promoters, officials at the HIAS rejected fertile alternatives such as Oregon and California, and instead chose to settle Russian Jews at Cotopaxi. According to historian Allen duPont Breck, twenty Russian families were sent by rail to the colony in 1882 . Upon arrival to the settlement, they were shocked to see dilapidated housing and a hostile environment not conducive to productive farming. More importantly, however, the men and women who were brought over to work this land were more accustomed to richer soils and in some cases had no experience in the practice 
of agriculture. After a particularly tough winter in 1882, some of the colonists began to abandon the colony for Denver, and by June of 1884 , the Jewish agricultural experiment near the Arkansas River had of ficially ended. Nevertheless, from this failure emerged the seeds of Jewish settlement in the West Side of Denver along Colfax Avenue. ${ }^{8}$

In the decades that followed, coreligionists from Russia, Romania, Poland, Lithuania and Hungary augmented the Cotopaxians who had resettled around Denver's main street, Colfax Avenue. These additional waves of settlement added to the vibrancy and complexity of the community and pushed Jewish settlement further west along the Colfax corridor. But Jews were not the only group building a community on the West Side, for closer to the core of the city lay an ethnic enclave that was slowly taking shape and would eventually come to dominate the makeup of the area into the late twentieth century and beyond.

During the 1920s and 1930s, growing numbers of Mexicans, mainly out of economic necessity, migrated from the coalfields of the south and the beet fields of the north to Denver. The late 1920s heralded the end of the halcyon days when coal was king in Colorado. Mine operators in southern Colorado towns like Walsenburg were hiring fewer men due to the increasing use of petroleum as a way to heat homes up and down the Front Range. Moreover, the ensuing Great Depression of the 1930s forced hardworking farm workers to abandon the beet field colonies of Weld and Larimer counties and look elsewhere for work. Some of these individuals eventually settled in the Auraria, Baker, and Lincoln sections of West Denver, and by the 1960s and early 1970s supplanted the older Jewish population further west. The permanent Mexican-American population for all of Denver exceeded 12,000 by 1940 , an impressive increase from 2,500 in the early 1920s. More importantly, however, the West Denver population of Mexican Americans for Baker, Auraria, and Lincoln was nearly 10,000 by 1970 . To put this in some perspective, the entire Jewish population for Colorado was estimated to be a little over 19,000 in 1958.9

Without question, the heart of the Mexican-American West Side was Auraria. One of the oldest sections of the city, Auraria was first home to Irish and German immigrants. Indeed, flourmills and breweries with their accompanying smells and sounds were common in this area. In

8 Breck, Centennial History, 74-80, Uchill, Pioneers, 173-174.

9 Richard Gould, The Life and Times of Richard Castro (Denver: Colorado Historical Society, 2007), 65-66; Carl Abbot, Stephen J. Leonard, and Thomas J. Noel, Colorado: A History of the Centennial State, 4th ed. (Boulder: University Press of Colorado, 2005), 357; George Rivera, Jr., Aileen F. Lucero, and Richard Castro, "Internal Colonialism in Colorado: The Westside Coalition and Barrio Control," in La Gente: Hispano History and Life in Colorado, ed.Vincent C. Debaca (Denver: Colorado Historical Society, 1998), 206; Breck, Centennial History, 321. 
1866, for example, a German immigrant by the name of Moritz Sigi founded the Colorado Brewery. By the turn of the century, John Good had purchased the brewery and renamed it after the Tivoli Gardens in Copenhagen, Denmark. The Tivoli would remain an important landmark in the neighborhood for decades to come, wetting the whistles of many Westsiders. ${ }^{10}$

Although breweries were important to the character of the neighborhood, so were its churches. In 1887, the Germans built St. Elizabeth's Catholic Church and School. That same year, the Irish, not to be outdone by the Germans, constructed St. Leo's Catholic Church. During this early period, there was even a small Orthodox congregation, Shearith Israel, which catered to Jewish businessmen working in the downtown area. ${ }^{11}$

By the first two decades of the twentieth century, these immigrants and their children began to move out of Auraria, renting their homes to a small but increasing stream of working-class Hispanics from Mexico, New Mexico, and the northern and southern regions of Colorado. In 1922, this population began to hold services in Spanish in the basement of St. Leo's Catholic Church. However, as it grew larger, this arrangement became untenable. Acutely aware of this a well-to-do Irish Catholic family, the Mullens, donated land and money to help found a new parish in the area. On March 21, 1926, St. Cajetan's Catholic Church officially opened. Built in the Spanish Colonial style, it soon became the center of Mexican-American life on the West Side, providing a school, clinic, and credit union. Moreover, mutual aid societies such as the Sociedad Mutualista Mexico and the Sociedad Protectora Hispana Americana began to form. ${ }^{12}$

In the 1940s, Mexican Americans began to settle in other parts of Denver closer in proximity to Jewish neighborhoods along the West Colfax corridor. West Side public schools such as Lake Junior High School, which had once enjoyed overwhelming Jewish majorities throughout the 1920 s and 1930s, now had to deal with a growing Mexican-American population. With this demographic shift came ethnic tension and outbreaks of violence in the streets and schools of the West Side. ${ }^{13}$

10 Jodi Michelle Summers, "Auraria: From Neighborhood to Campus" (Masters's thesis, University of Colorado, Denver, 2003), 32-39.

11 Summers, "Auraria," 32-39; Jeanne Abrams, Jewish Denver, 1859-1940 (Charleston: Arcadia Press, 2007), 69.

12 Summers, "Auraria," 32-39: Abbot, Leonard, and Noel, Colorado, 357.

13 Abbot, Leonard and Noel, Colorado, 357; Michael J. Zelinger, West Side Story Relived (Denver: J. Wandell Press, 1987), 158. 
Contrasts: Jews, Mexicans, Racial Identity, and the Formation of the Lake Junior High School Human Relations

COUNCIL

On Friday, September 30, 1949, three Denver Police Department squad cars sped toward West Sixteenth Avenue and Newton Street, near Lake Junior High School. A "gang battle," reportedly between thirty "Spanish-American" and "Jewish" students had broken out with an estimated crowd of three hundred spectators watching the melee. Before the police arrived, however, a quick thinking housewife with a garden hose had broken it up-literally dowsing the flames of racial discontent. No one was hurt, but it made for an eye-catching story in the Rocky Mountain News. ${ }^{14}$

Fights between Jews and Mexican Americans were familiar sites along the West Side. However, the key difference this time was the scale and reaction that this particular one engendered from within Denver's Jewish and Mexican-American communities. Most likely born of the News's September 30 article, questions began to be raised, especially by the local Jewish press, as to how things had gotten so out of hand and what could be done about it. For example, the Intermountain Jewish News reported that in the wake of the schoolyard fight "complete Jewish cooperation" and "inter-racial friendship" was being sought in order to identify and remedy the underlying cause of the situation. The Anti-Defamation League of B'nai B'rith (ADL), a well-respected Jewish advocacy and intergroup relations organization, even intervened in order to make sense of the circumstances. And while the Jewish community was attempting to comprehend what had occurred near Lake, Mexican-American families living in the area were beginning their own initial exploration into what exactly went wrong and what could be done about it. ${ }^{15}$

The first meeting held by Lake's Mexican-American residents took place on October 3. Sponsored by the Rude Community Center, it assembled teachers, students, and community leaders from the Spanish speaking population to discuss the incident. People with names like Del Toro, Guzman, Rodriguez, Borrego, Ulibarri, Mendez, and Maes sat in the au-

14 Rocky Mountain News, October 1, 1949, 22.

15 Although no other instance of violence between Jews and Mexican Americans on the West Side of Denver received the press coverage that the "gang fight" at Lake did, reports from Lake Junior High School of ficials and the Anti-Defamation League suggest that they were common enough. Moreover, the unidentified woman in the October 1, 1949 article in the Rocky Mountain News stated, "The trouble . . . [between Jewish and Mexican-American] students has been going on for a long time," suggesting a pattern. For examples of additional conflicts between Jews and Mexican Americans on the West Side see Nathan Perlmutter to L.E. Sidman, October 4, 1949, box 2, Commission on Community Relations, Denver Public Library, Western History Collection (hereafter cited as CCR) and Principal's Report and Recommendations to the Lake Human Relations Council, March 2, 1950, box 2, CCR; Intermountain Jewish News, October 6, 1949, 1. 
dience. No Jews attended. The stated purpose of the meeting was as follows: to make sure the assembled community leaders knew all the "facts" of the incident; that the incident was strictly a school issue; and to determine whether or not there was systemic ill-will between Jews and Mexican Americans in the West Side neighborhood "and, if so, it is the job of the persons concerned . . . to plan jointly for and to work on such activities as will eradicate undesirable attitudes between [the] groups." 16

With regard to the first purpose, Tom Borrego, a Mexican-American teacher at Lake, informed those in attendance that on the day before the fight a Jewish boy was getting a drink of water when he was snapped with a rubber band. The boy allegedly snapped back by calling a Mexican-American boy near him a "dirty Mexican." Borrego reasoned that this might have been a cause of the September 30 incident. Furthermore, by the time the fight was about to occur, older brothers, probably from nearby North High School, came to help settle the score between the two middle schoolers. Finally, Chicano students who were at the meeting confirmed that no weapons had been used, and that there was not a crowd of hundreds watching the fist fight as the News had reported. ${ }^{17}$

Indeed, participants at the gathering fumed with anger at how Denver's oldest newspaper had portrayed the incident to the greater Denver community. For example, why did the News even have to reveal the ethnicities of the two groups? Moreover, the paper reported that "Spanish-American boys" were "chasing Jewish boys," making Mexican Americans appear to be hoodlums in the eyes of other Denverites. ${ }^{18}$

Statements such as these suggest that this was an occasion when the vulnerable social condition of the Mexican-American community came into play. Discrimination against Mexican Americans was widespread in Colorado, affecting every sector of life, including health care, recreation, schooling, law enforcement, and employment. Furthermore, it was not until the 1950s that Mexican-American organizations such as the GI Forum, the League of Latin American Citizens, the Colorado Latin American Conference, and the Latin American Education Foundation, began to draw much needed attention to these serious social inequities. Perhaps more tellingly, however, Mexican Americans living in Colorado and the rest of the country would have to wait until 1975 for the United States

16 Report of Meeting Held Concerning "Lake Junior High Incident" reported in Rocky Mountain News, October 3, 1949, box 2, CCR.

17 Report of Meeting Held Concerning "Lake Junior High Incident" reported in Rocky Mountain News, October 3, 1949, box 2, CCR.

18 Report of Meeting Held Concerning "Lake Junior High Incident" reported in Rocky Mountain News, October 3, 1949, box 2, CCR. More than just "chasing" Jewish boys, the News portrayed a situation where Jewish students were "running home from school" in panic. 
Congress to extend the Voting Rights Act of 1965 to them and other Latinos. ${ }^{19}$

As discussion in the meeting moved away from concerns about the News's portrayal of the fight, the issue of day-to-day interactions with Jews arose. Everyone unanimously agreed that the tension between the two groups had been building for some time. For example, a rumor had been circulating among Mexican-American students at Lake that one of their own had left the neighborhood and "joined the 'Jewish religion' and the other boys did not like him for that and intended to get him for his 'High Hattedness' [snobbishness]." In addition, Mrs. Fernandez, the current president of the Parent-Teacher Association for Lake (PTA), remarked: "Many Spanish-American parents felt that the Jewish children think Lake belongs to them." And Mrs. Guzman, a former Lake PTA president, expressed that Jews initially made Mexican Americans feel unwelcome and uncomfortable when they went to PTA meetings. On the other hand, Guzman was more evenhanded when she articulated that there was undoubtedly prejudice on both sides and that there needed to be more self-examination between the two groups. The next issue for debate was the presence of law enforcement in the neighborhood. ${ }^{20}$

For many Mexican Americans at the meeting, Jews were to blame for the police patrols in the area. In turn, this amplified Mexican-American feelings of uneasiness and mistrust toward Jews. Were Mexican Americans being accused of something? Were the squad cars present because the Jewish community had the economic and political pull to get them assigned there, acting as bodyguards to "protect Jewish children from Spanish-American children[?]" This anxiety filled language appears to point toward something more deep-seated, specifically, an acute class-divide within the West Side community itself. ${ }^{21}$

Jews in the area were upwardly mobile, owned their own businesses and homes, participated in significant numbers in the professions, and had an active civic life. Mexican Americans, on the other hand, were solidly working class, in many cases economically disadvantaged, and politically disenfranchised. This, perhaps, helps to explain the feeling among Mexican Americans that Jews were snobs who preyed on economically vulnerable Chicanos. Reminiscing about life in Auraria, Russel DeLeon, a Mexican American, recounted that a Jew owned "the corner store, and he had high prices on his stuff." DeLeon's sentiment is

19 Abbot, Leonard, and Noel, Colorado, 358; F. Arturo Rosales, Chicano! The History of the Mexican American Civil Rights Movement (Houston: Arte Público Press of the University of Houston, 1996), 282.

20 Report of Meeting Held Concerning "Lake Junior High Incident" reported in Rocky Mountain News, October 3, 1949, box 2, CCR.

21 Report of Meeting Held Concerning "Lake Junior High Incident" reported in Rocky Mountain News, October 3, 1949, box 2, CCR. 
indicative of a middleman minority dynamic, where, according to sociologists Adalberto Aguire, Jr. and Jonathan H. Turner, the "clients of middleman minorities, especially those in the lower social classes . . . tend to exhibit hostility toward the petitie bourgeoisie, who are viewed as mercenary and exploitive." Consequently, it did not matter whether Jews were in truth economically exploitive of Mexican Americans; what mattered was that Mexican Americans firmly believed that Jews were, which greatly intensified racial tension on the West Side. ${ }^{22}$

At the conclusion of the meeting, the group recommended that local churches and organizations combat prejudicial attitudes toward Jews during sermons and social activities, and that all parents make a better effort at being involved in the lives of their children. It is likely that these recommendations fell flat, however, for they excluded the Jewish community from the dialogue and lacked any apparent follow through. On the other hand, this proved to be a crucial moment of self-introspection for the Mexican-American community on the West Side. It started to come to terms with the unsettling reality that there was a serious problem between Jews and Mexican Americans in the area. Meanwhile, the Jewish community and one of its preeminent intergroup agencies, the ADL, was busy investigating and documenting what had supposedly happened near Lake and what lay at the root of it. ${ }^{23}$

On the morning of October 1, the same day that the News broke the story of the September 30 disorder near Lake, the ADL dispatched Nathan Perlmutter, a representative of the organization to investigate. Over the course of two days, Perlmutter interviewed five eyewitnesses to the fight and compiled a detailed report based upon his findings. More than just a dry recounting of the September 30 melee, this report provides a rare, but admittedly limited glimpse into the attitudes of Denver's Jews toward Mexican Americans. More importantly, however, it suggests that Jews living on the West Side were adopting a regional definition of whiteness. ${ }^{24}$

In his influential study, The Price of Whiteness: Jews, Race, and American Identity, historian Eric L. Goldstein found that geography played an important role in how Jews constructed their racial identities. Moreover, it was "how Jews negotiated their place in a complex racial world" that mattered more than the cumbersome question of how Jews

22 Magdelena Gallegos, Auraria Remembered: An Oral History by Former Residents of Denver's Westside neighbor Compiled by the Community College of Denver Staff and Honors Program Students (Denver: Community College of Denver, 1991), 13; Adalberto Aguirre, Jr. and Jonathan H. Turner, American Ethnicity: The Dynamics and Consequences of Discrimination, 5th ed. (Boston: McGraw Hill, 2007), 38-39.

23 Report of Meeting Held Concerning "Lake Junior High Incident" reported in Rocky Mountain News, October 3, 1949, box 2, CCR.

24 Nathan Perlmutter to L.E. Sidman, October 4, 1949, box 2 CCR; Uchil, Pioneers, 318. 
became white, which was unsuccessfully answered by anthropologist Karen Brodkin. Indeed, Ellen Eisenberg, building on Goldstein's astute observation of "a complex racial world," demonstrated that Jews living in California, Oregon and Washington State "reflected the peculiarities of a western ethnic landscape in which ... [they] were part of an 'Anglo' world that was defined, in part, by contrast with Japanese Americans, the region's most conspicuous non-white group." 25

In a similar way, the racial peculiarities of the Rocky Mountain West most likely meant that some Jews were laying claim to an Anglo identity by contrasting themselves with Mexican Americans-one of the region's most loathed and obvious ethnoracial groups. Moreover, in a state like Colorado, which had a recent history of anti-Mexican sentiment, this may have been one of the best ways for Jews to assert membership in the broader pan-ethnic white community and distance themselves from Mexicans. Indeed, during the Great Depression, Governor Edwin Johnson declared martial law along the border with New Mexico and deployed the Colorado National Guard there to keep Mexicans out of the state. In similar acts of illegality and xenophobia, he demanded the expulsion of Mexican beet workers and deported MexicanAmerican citizens from Colorado Springs. Statewide, relief agencies and county commissioners routinely lamented seeing Spanish surnamed individuals on their roles. In Colorado's schools children of Mexican heritage dealt with racially inflected taunts from Anglo children, ranging from "dirty Mexican" to "greaser." And as one previously demonstrated, Jewish school children were not above using identical racial epitaphs against Mexican-American classmates. Thus, whenever Jews in Denver engaged in discriminatory acts against Mexican Americans, they were likely laying claim to a decidedly white identity. ${ }^{26}$

However, affirming such an identity held special significance in a city like Denver where there was a history of anti-Semitism. In fact, even well established pioneer Jewish families were not immune from the phenomenon. Amy Salomon, for example, remembered her classmates heaving rocks at her and calling her a Christ killer. ${ }^{27}$ Moreover, in 1903, a popular Unitarian minister in the city declared, "It's the Jewish race, not the Jewish church that is disliked. If free intermarriage with us [Anglos]

25 Eric L. Goldstein, The Price of Whiteness: Jews, Race, and American Identity (Princeton, NJ: Princeton University Press, 2006), 5, 52-55; Karen Brodkin, How Jews Became White Folks and What that Says about Race in America (New Brunswick: Rutgers University Press, 1998); Eisenberg, The First to Cry Down, 31.

26 Sarah Deutsch, No Separate Refuge: Culture, Class, and Gender on an Anglo-Hispanic Frontier in the American Southwest, 1880-1940 (New York: Oxford University Press, 1987), 165-167, 140.

27. Stephen J. Leonard and Thomas J. Noel, Denver: Mining Camp to Metropolis (Niwot, CO: University Press of Colorado), 194. 
should be adopted the race hatred would vanish in three generations." 28 Although disturbing, these were not the worst forms of anti-Semitism that the Mile-High City had to offer.

On Christmas day in 1905-the very same year hundreds of Jews were being massacred in the Russian Empire-a Gentile mob successfully lynched Jacob Weisskind and severely injured Mendel Slotkin. ${ }^{29}$ According to the Aspen Democrat, "The only excuse for the attack is that the two Jews were working, loading a car with scrap iron instead of resting in observance of the Christmas holiday." 30 Philip Lynd and Philip Keiser, two Germans, orchestrated the rampage. The mob beat Weisskind and Slotkin with stones, bricks and iron, slashing their faces and breaking their bones; in fact, they "crushed" Weisskind's skull. While doing this, Lynd and Keiser reportedly yelled out that they were "aveng[ing] the blood of Christ by shedding the blood of . . . Christkillers." 31 The story made national news two days later when the Los Angeles Times remarked that the situation in Denver "seemed just like Russia." 32 Slotkin recovered from his wounds, but Weisskind died from complications stemming from his head injury on February $14 .{ }^{33}$ The Jewish Outlook, Denver's only Jewish weekly at the time, later reported on the trial and conviction of Lynd and Keiser, contrasting in black and white the impassioned pleas of the prosecutor, Greely Whitford, for a verdict of murder in the first degree with the jury's shocking verdicts of voluntary and involuntary manslaughter. ${ }^{34}$ The sentences, four to six years for Lynd and seven months fourteen days for Keiser, were "altogether too light for the grave crime." 35 A third ringleader, an Irishman by

28 Jewish Outlook, December 4, 1903, 8. This statement is typical of Progressive era eugenics-based anti-Semitism that advocated Jews' racial distinctiveness and inferiority. See Christine Rosen, Preaching Eugenics: Religious Leaders and the American Eugenics Movement (New York: Oxford University Press, 2004), 85-111.

29 According to the National Association for the Advancement of Colored People, in order for a lynching to have occurred the following criteria must be met: "There must be evidence that someone was killed; the killing must have occurred illegally; three or more persons must have taken part in the killing; and the killers must have been serving justice or tradition. Cited at Project HAL: Historical American Lynching Data Collection Project, people.uncw.edu/hinese/HAL/HAL\%20Web\%20Page.htm. The best-known instance of a Jew being lynched in American history is that of Leo Frank. Frank, a northern Jew and pencil factory manager, was accused of murdering a teenaged employee, Mary Phagan, in 1913. After his death sentence was commuted by the Governor of Georgia, Frank was dragged from his prison cell and hung. See Leonard Dinnerstein, The Leo Frank Case (New York: Columbia University Press, 1968).

30 Aspen Democrat, December 27, 1905, 1

31 Jewish Outlook, May 4, 1906, 6.

32 Los Angeles Times, December 27, 1905, 11.

33 Jewish Outlook, February 16, 1906, 10.

34 Jewish Outlook, May 4, 1906, 6.

35 Jewish Outlook, May 18, 1906, 6. 
the name of Sonny Bohanna, jumped bail shortly after the lynching. ${ }^{36}$ In 1907, two more Russian Jews, Michael Weisblye and Tevyah Bokser, were "brutally murdered" on West Colfax. Their assailants, Harold McKnaw and Wilbur F. Gilmer received similarly light sentences. ${ }^{37}$ In contrast to these laughable punishments for murder, a Jewish youth by the name of Nathan Goldstein was sentenced to five to ten years in the state penitentiary for petty larceny in 1909. To add insult to injury, the presiding judge claimed that he was being lenient on Goldstein, who was also suffering from a severe case of tuberculosis. ${ }^{38}$

In the 1920s, Denver's Jews had more reason to feel insecure with the ascendency of the Ku Klux Klan. By 1925 the mayor of Denver, the state governor, and one U.S. senator were known to be Klansmen. Keenly aware of who wielded power in the Mile-High City, most Jews remained studiously silent in an effort to not incur the wrath of the blatantly anti-Semitic organization. However, this silence did not stop the Klan from boycotting Jewish businesses and parading through the Jewish West Side as they were on their way to burn a cross on Table Mountain above the city of Golden. ${ }^{39}$ More tellingly, however, Denver's most prominent and respected Reform rabbi, William S. Friedman, urged all of his congregants at Temple Emanuel-the city's largest and oldest synagogue-not to bring attention to themselves while the Klan ruled the city. ${ }^{40}$ Furthermore, Friedman opposed a plan by local attorney Charles Ginsberg to take out an advertisement in the Denver Post condemning the Klan's corruption of the judiciary. ${ }^{41}$ On the other hand, there was good reason to remain silent and inconspicuous when it came to the Invisible Empire. Indeed, William W. Clawson had cold bloodedly murdered Joseph Zuckerman and been acquitted by a jury of his peers. Reporting on the verdict in 1920, the Denver Jewish News declared that it was a "miscarriage of justice." In the same article, attorney Joseph F. Jaffa remarked: "The season for the ruthless mauling and slaying of Jewish horse and cattle traders and peddlers seems to be an open one in Denver. At least as far back as I can recall it has never been closed." 42 More than four decades after the trial, however, Ginsberg disclosed that

36 Jewish Outlook, May 18, 1906, 6. For additional details on the lynching of Weisskind see Rocky Mountain News, December 26, 10: Aspen Democrat, January 4, 1906, 1. The News's account of the assault on Weisskind and Slotkin numbered the mob at fifteen to twenty men.

37 Jewish Outlook, February 15, 1907, 1; Jewish Outlook, May 10, 1907, 1.

38 Denver Times, March 6, 1909, 2.

39 Charles Ginsberg, interview by James Harlan Davis, tape recording, May 5, 1963, Denver Public Library, Western History Collection.

40 Phil Goodstein, In the Shadow of the Klan: When the KKK Ruled Denver, 1920-1926 (Denver: New Social Publications, 2006), 74-77.

41 Charles Ginsberg interview.

42 Denver Jewish News, May 5, 1920, 1. 
the not guilty verdict was attributable to the hooded nature of the judge, jury, and the defendant. ${ }^{43}$

But in more recent memory, Jews were routinely denied membership in many of the elite men's clubs, including the Denver Club, University Club, and Denver Athletic Club. Furthermore, the News explicitly linked Jewish children with Mexican children, conjoining them in print and in the minds of thousands of readers. On the other hand, Jews had achieved a great deal of success in the city as prominent businessmen and civic leaders. For example, Edward Monash, David May, and Leopold Guldman had owned extremely successful department stores; Louis Anfenger had made his fortune in banking; and Wolfe Londoner had even been elected mayor of the Mile-High City in 1889. Despite this economic and political success, however, living in close proximity to Mexican Americans, in addition to a conspicuous history of anti-Semitism in the city, must have engendered anxious feelings in Jews, compelling them to wonder where they actually stood in the racial hierarchy of Denver. ${ }^{44}$

Therefore, it is not surprising that in Perlmutter's report initial rumors about the fight within the Jewish community were circulated with erroneous and inflammatory details of Mexican-American youths knifing Jewish school children-mimicking an Anglo attitude of Mexicans as violent and sinister. In a similar fashion, interviewees in Perlmutter's report also imagined Mexican-American youths with menacing weapons. For example, the Gamzey children, Allan Boxer, and Mrs. Zellinger (the unidentified women in the News article who hosed down the combatants) consistently accused Mexican-American students of carrying and using knives, even though no such weapons were actually used or seen during the September 30 melee. In addition to frightening "killing knives," Perlmutter detailed how Jewish children associated other brutish weapons with overly aggressive Mexican-American youths. "Spanish-American children," he wrote, "fought with taps on their shoes, chains, boards and buckled belts." But did this mean, as Perlmutter concluded, that Jewish boys systemically feared their Mexican American peers? If that was the case, then Jewish boys would have most likely avoided physical confrontations with well-armed Mexican-American boys. On the other hand, a

43 Charles Ginsberg interview.

44 Pearl Alperstein, interview by Anna Dean Kepper, tape recording, July 13, 1978, Ira M. Beck Memorial Archives, University of Denver; Sheldon Steinhauser, interview by Michael Lee, digital recording, September 11, 2009; Uchill, Pioneers, 94, 144; Breck, Centennial History, 120. Londoner, however, was only Jewish by descent. In actuality, he was a member of the Episcopalian Church and rarely associated with Denver's Jewish community. Moreover, he was goaded by a local newspaper for his Jewish past during the 1889 election. Finally, Londoner was forced to resign from his of fice in March 1891 due to acquisitions that the election was fraudulent. See Uchill, Pioneers, 146-147. 
more likely explanation might be that Jewish boys actively sought out fights with their Mexican-American counterparts in order to assert Jewish, and by extension Anglo dominance over the neighborhood. Had not their fathers achieved similar ends through their businesses and professions, engendering a feeling-although probably unjustified-among Mexican Americans that Jews unfairly overcharged for goods and services in the neighborhood? Moreover, Perlmutter found in a phone interview with Mrs. Zellinger that Jewish boys routinely objected to suggestions of extra police patrols in the area because it might reflect upon them as "sissies." Allan Boxer, for example, recounted a fight where his mettle as a budding white Jewish male was tested against no less than " 15 or 20 " Mexican-American boys who ruffed him up in the presence of two girls he was walking home. With regard to the Lake incident itself, it was a Jewish student, Clifton Katz, who had "passed the rumor around the school that Sam Handler [a Jewish boy] had 'beat up' Pete Pedilla [a Mexican-American boy]," igniting the series of events that led to the confrontation near Lake. However, this important detail was relayed to Perlmutter with a qualification-that Katz had been ordered by Pedilla to spread the rumor in the first place. So how can this inconsistency be properly reconciled? ${ }^{45}$

It appears that Perlmutter gathered this important piece of information from Saul Gayton, a Mexican-American boy who was friends with Jews in the neighborhood. Gayton characterized himself in the interview as being "on the side of the Jewish boys." Moreover, Gayton went to great lengths to articulate to Perlmutter the moral depravity of his own Mexican-American peers by stating that they "drink intoxicants whereas the Jewish friends of his do not." Furthermore, the Jewish boys, according to Gayton, grouped together for protection, not necessarily to attack Mexican-American students. Simply put, Gayton most likely fabricated the detail about Pedilla ordering Katz to spread the gossip in order to shift responsibility onto the Mexican-American participants and away from his Jewish friends, thereby absolving them of any blame. It worked, for Perlmutter underlined this detail in his report and recommended that the League use Gayton "in any school program decided upon by the ADL and the school authorities." Unsurprisingly, Gayton "impressed" Perlmutter as "an unusually fine young man"; however, this was not because of Gayton's apparent honesty or decorum, but because he recapitulated a curiously Anglo attitude of defective Mexican morality that was familiar to Perlmutter and other ADL officials. This is by no means a

45 Nathan Perlmutter to L.E. Sidman, October 4, 1949, box 2, CCR; Mauricio Mazón, The Zoot-Suit Riots: The Psychology of Symbolic Annihilation (Austin: University of Texas Press, 1984), 81-82; Arnoldo De León, They Called Them Greasers: Anglo Attitudes Toward Mexicans in Texas, 1821-1900 (Austin: University of Texas Press, 1983), 87. 
suggestion that Gayton wanted to be white, but that his attitudes toward other Mexican Americans closely resembled those of the Jews with whom he associated and called friends. On the other hand, understanding Gayton's mentality is beyond the scope of this study, and speaks more to the state of Mexican-American identity in the postwar period more than anything else. Moreover, Perlmutter might have found Gayton "unusual" simply because he expressed sympathetic attitudes toward Jews. ${ }^{46}$

Although Perlmutter was veiled in his attitudes toward Mexican Americans, other ADL officials in Denver were not. For example, in a confidential letter to his personal files J. Peter Brunswick remarked:

As a reaction to the treatment and position of the Jewish child, [better socioeconomic status] the Spanish American child manifests an aggression complex, which is the result of his subconscious feeling of inferiority. ... It is obvious that the low academic quotient is a result of a lack of appreciation of education and school. It may be safely assumed that few of the Spanish-American children are being kept home to study, by their parents, who in most cases, are even less educated than their children. ${ }^{47}$

Historian Arnoldo De León found that Anglos in Texas systematically viewed Mexican culture as "backward," "primitive," and "firmly against innovation." Moreover, De León continued, Anglos habitually identified "Mexican sections of urban areas with vice, licentiousness, and moral degradation." But most importantly, as one alluded to earlier, there was a long-standing Anglo tradition in the West of perceiving Mexicans as cruel and naturally inclined to violence. For example, stories of Mexican atrocities against whites in the Lone Star State were common, usually stirring up passionate feelings of revenge among white populations. Furthermore, Sarah Deutsch found that the exact same stereotypes pervaded in Colorado. "Visions of lawless and irresponsible hordes," she wrote, "visions unanchored by statistics, floated in the public mind." Therefore, in a broader historical context, Jews' attitudes toward Mexicans in Denver were remarkably similar to their Anglo contemporaries. ${ }^{48}$

Despite this pervasively negative attitude toward Mexicans, Perlmutter and other ADL officials did recognize that there was a severe problem between the two groups and that something had to be done about it; whether Jews were at least partly to blame for the situation was

46 Nathan Perlmutter to L.E. Sidman, October 4, 1949, box 2, CCR.

47 J. Peter Brunswick to Files, October 4, 1949, box 2, CCR.

48 De León, They Called Them Greasers, 31, 46, 87-103; Deutsch, No Separate Refuge, 151-152. 
another story. Regardless, the next step in dealing with the neighborhood's interracial tension and violence went beyond conducting interviews, or even the writing of detailed reports, (which the ADL was quite good at). Indeed, it took the form of an interracial neighborhood council where Jews, Mexican Americans, and Anglos could meet, talk, and "develop better understandings . . . between pupils, teachers, parents and other people in the Lake community." 49

Established in November of 1949, the Lake Junior High School Human Relations Council (LHRC) was emblematic of a national trend that historian Stuart Svonkin identified as the "intergroup relations movement." This movement developed a set of principles that advocated "improved relations among racial, ethnic, and religious groups"; equal opportunity for all groups"; and "improvement of the quality of life within these groups." Within this multiethnic movement, Svonkin continued, "Jewish organizations played the leading role in defining . . tactics and objectives." For example, in the aftermath of the 1943 Zoot Suit Riots in Los Angeles (a severe outbreak of anti-Mexican sentiment), the Community Relations Council of the Jewish Federation Council of Los Angeles led the way in fostering productive partnerships between ethnic groups in the city. And in other western cities, such as San Francisco, Seattle, and Portland, Jews spearheaded the formation of committees and councils that advocated equality and cooperation. Furthermore, secular Jewish agencies like the ADL and the American Jewish Committee, which had originally been created to combat anti-Semitism, even embraced the principles of the intergroup relations movement by reaching out to African Americans and other groups in order to combat discrimination in housing, education and employment. And for those secular Jewish agencies in particular, the struggle against anti-Semitism was strongly associated with the struggle against all forms of prejudice; in essence, what affected one group affected all groups. ${ }^{50}$

On the other hand, as Svonkin has observed, the staff members of these Jewish agencies and other intergroup relations organizations also believed that eradicating social conflict benefited the country as a whole. In essence, fostering harmonious intergroup relations during World War II and into the Cold War period meant undermining the enemies of democracy both domestically and internationally. Therefore, although Jews stridently contrasted themselves with Mexican Americans, this did not necessarily preclude a powerful ideological desire, especially among

49 Principal's Report and Recommendations to the Lake Human Relations Council, March 2, 1950, box 2, CCR.

50 Stuart Svonkin, Jews Against Prejudice: American Jews and the Fight for Civil Liberties (New York: Columbia University Press, 1997), 1,2, 28; Eisenberg, First to Cry Down, 154,155 . I established the approximate date of formation for the LHRC by using the three remaining minutes of the organization and the Intermountain Jewish News. 
members of secular Jewish agencies like the ADL, to establish peace, understanding and "inter-racial friendship" in the community. This meant that an ADL official like Brunswick could privately harbor ill will toward Mexicans, but simultaneously believe that it was his patriotic duty as an American to foster interracial tranquility in the neighborhood. In fact, Brunswick served as the ADL's representative on the LHRC. ${ }^{51}$

Evidence suggests that the ADL, along with other ethnic and religious advocacy agencies in Denver, played an important role in guiding the LHRC in its program of intergroup relations at Lake. The few surviving minutes from the LHRC and records from the ADL hint at a bifurcated approach to the problems at the school: a sociological study of the area and activities that fostered harmony and understanding between groups. As was indicative of intergroup relations organizations of the period, the LHRC employed "scientific research to analyze and counteract ethnic, religious, and racial bigotry." In other words, the approach to eradicating prejudice was similar to fighting a virulent disease, such as tuberculosis or polio. For example, the LHRC, in conjunction with its member organizations, which consisted of the ADL, the Mayor's Human Relations Commission, the Denver Unity Council, the Latin American Education Council, Denver Public Schools (DPS), and the Urban League, developed a comprehensive survey to measure "the basic intercultural problems in the community and to chart the course of action in their solution." Although the raw data and conclusions from this study are likely lost, a surviving copy of the questionnaire sent out to Lake's parents provides some idea as to how the LHRC and its members approached the difficulties at Lake. Many of the questions posed by the survey focused on the possible causes of conflict within the community; for example, lack of good parenting, the staff at Lake, socioeconomic disparities, and ethnoreligious misunderstanding. Still other queries asked how those problems could be best addressed. Some of the solutions, for instance, ranged from increased police patrols to more activities that encouraged intergroup understanding. The study's findings, it is reasonable to conclude, were put to good use by the LHRC and its member organizations. ${ }^{52}$

51 Svonkin, Jews Against Prejudice, 5; Intermountain Jewish News, October 6, 1949, 1; Lake Junior High School Human Relations Council Minutes, March 2, 1950, box 2.

52 Svonkin, Jews Against Prejudice, 4, 30. The Mayor's Human Relations Committee/ Commission was formed by Mayor Quigg Newton in 1947 to study the socioeconomic conditions of Denver's minorities. The Latin American Education Council, later renamed the Latin American Education Fund, was established in Denver in 1949 to provide grants and loans to Mexican-American youths who were college bound. The Denver branch of the Urban League was established in 1947 for the economic and social improvement of African Americans. See James A. Atkins, Human Relations in Colorado: A Historical Record (Denver: Colorado Department of Education, 1968), 159-162, 219, 135-141. Well-to-do African Americans and whites in the city organized the Denver Unity Council in 1944. Like many intergroup agencies 
By September 1950, the Intermountain Jewish News reported that conditions at Lake had markedly improved since the previous year's violence. DPS made physical improvements to the school, and extra "athletic facilities and equipment are planned." Moreover, representatives from the LHRC told the Intermountain Jewish News that teachers at Lake were making efforts at "better understanding" between students by "pointing out the contributions of various racial and religious groups at every opportunity." Bert Levin, a Jewish student at Lake, "opined that assemblies dealing with interracial relations last year "did a lot of good. As you go thru Lake . . . you make these kids your friends,' referring to boys and girls of other faiths." However, other students at the school, including Connie Martinez and Freyda Blumberg were more reluctant, cautioning that interracial cooperation and understanding should be allowed to grow naturally and not be forced. But forced it was. ${ }^{53}$

In conjunction with DPS, the ADL championed joint observances of Chanukah and Christmas at Lake and other schools within the district. Michael L. Freed, mountain states regional director of the ADL, expressed to Harry Nicholson, Lake's principal, his "gratification over your splendid joint observance I was privileged to witness yesterday. In my opinion it reflected a fine understanding about, and keen sensitivity of, the many complex problems inherent in the subject matter." In fact, throughout the country the ADL and other Jewish organizations were advocating for joint observances of Christmas and Chanukah in order to build harmony and intergroup understanding. In Elizabeth, New Jersey, for example, the National Jewish Post reported that a Reform temple, Beth El, had "launched the community's first Hanukah workshop for public school principals and teachers" to learn the history and customs of the Festival of Lights. It is fair to assume that programs such as the ones described above played an important role in easing intergroup tension at Lake and other schools in Denver and across the country. However, of more consequence to this case study was the movement of Jews out of the West Side, which likely brought about a gradual end to the interracial tension and violence between the two groups and to the LHRC. ${ }^{54}$

of this period, its goal was to fight for the equality of all citizens, regardless of race. See Nina Mjagkiji, Organizing Black America: An Encyclopodia of African American Associations (New York: Garland Publishing, 2001), 213. Principal's Report and Recommendations to the Lake Human Relations Council, March 2, 1950, box 2, CCR; Lake Junior High School Questionnaire for Parents, May 29, 1950, box 2, CCR.

53 Intermountain Jewish News, September 5, 1950, 1.

54 Michael L. Freed to Harry Nicholson, December 20, 1951, folder 2, box 11, The AntiDefamation League of B'nai B'rith Lodge 171, Ira M. Beck Memorial Archives, Special Collections and Archives, Penrose Library, University of Denver (hereafter cited as ADL); $\mathrm{Na}$ tional Jewish Post, November 28, 1952, clipping, folder 3, box 11, ADL. For a summation of joint observances in Denver see Christmas-Chanukah Observances: The Denver Experiment, 
By the late 1950s and early 1960s, Jews on the West Side began to abandon their older homes for the newer, whiter, and more fashionable neighborhood of Hilltop in southeastern Denver. Indeed, by 1964 the West Side's only Jewish community center, the Guldman Center, had been shutdown and a new one established near Hilltop. On the other hand, for those Jews who could not afford to move or chose to stay, they found that they had to adapt in the wake of a rapidly changing West Side. For example, Phil's Grocery, a fixture in the neighborhood since the late 1940s, began to sell Mexican food alongside Jewish food. Moreover, a Spanish language newspaper in Denver honored Phil Rosen, the proprietor of the establishment, for his "fairness and concern for his customers"-a noticeable change from previous accusations of Jewish merchants preying on economically vulnerable Mexicans. ${ }^{55}$

But even though individual Jews and their families were moving out of the West Side, signaling their literal geographic movement into white Denver, this did not mean that secular Jewish agencies like the ADL and the American Jewish Committee were abandoning their intergroup relations principles or forgetting the social and economic plight of Mexican Americans. In fact, the rise of the Chicano Movement in Denver and across the West during the late 1960s and early 1970s meant that those agencies would utilize their resources in an important effort to advocate directly on behalf of Mexican Americans-primarily through the development and implementation of educational programming in secondary school and college curriculums and by founding, financing, and administratively supporting Mexican-American organizations. For example, in the late 1960s the ADL launched "Project Mexican American" in an effort to eradicate cultural insensitivity toward Mexican Americans in western school districts and colleges. And the American Jewish Committee helped found Centro Cultural, a Mexican-American civil rights agency in Denver. ${ }^{56}$

\section{Conclusion}

The 1949 gang battle, the ADL's response to it through the LHRC, and a very real history of anti-Semitism, suggest that Denver's Jews were not as at home in their scenic Rocky Mountain setting as previously thought; in fact, evidence suggests that they were "uneasy at home." To be sure, Jews had achieved a great degree of political, professional and

Draft of Talk given at Temple Men's Club, Wilshire Boulevard, Los Angeles, CA, March 7 , 1956, folder 6, Box 11, ADL.

55 Uchill, Pioneers, 317-318; Phil Goodstein, Exploring Jewish Colorado (Denver: The Rocky Mountain Jewish Historical Society, 1992), 58; Zelinger, West Side Story, 77.

56 See file folder 11, Box 18, ADL for a full account of "Project Mexican"; Intermountain Jewish News, February 14, 1969, 12. 
economic success in Denver, helping to build a remarkable city. However, that outward veneer of success and self-assuredness did not necessarily guarantee that Jews felt inwardly secure about their place in the city. Indeed, that internal insecurity occasionally manifested itself in the form of behavior and language that stridently contrasted Jews with Mexican Americans. Furthermore, exclusion from elite men's clubs, being called Christ killers, stoning at school, instances of murder and outright lynching, all created a painful memory of anti-Semitism within the city's Jewry. Compounding this situation was also the Jewish West Side's proximity to a growing Mexican-American enclave, which only intensified the desire for distancing. Moreover, even ADL officials succumbed to this phenomenon, manufacturing contrasts with Mexican Americans, especially by pointing out perceived psychological deficiencies. This palpable uneasiness, one suggests, only made Jews on the West Side breath deeper the toxic fumes of anti-Mexican sentiment that existed in Denver, Colorado and the West-all in an effort to shape a racial identity that was more Anglo than Other. ${ }^{57}$

However, intergroup relations principles, combined with an acute crisis and embarrassing press coverage, required Jews to work toward some kind of cooperation with their Mexican-American neighbors, allowing for the organization of an interracial council that was devoted to reestablishing calm on the West Side. Nevertheless, it was those very same principles that permitted Jews like J. Peter Brunswick to inwardly harbor scorn toward Mexican Americans, but outwardly serve on councils with them in the spirit of cooperation. Indeed, cooperating with Mexican Americans during the 1940s and 1950s was primarily in the interest of domestic tranquility and fighting anti-Semitism, not necessarily to better the condition of Mexican Americans in Denver; in fact, if that occurred, then it was a bonus, but not an intended goal. And it would not be until the 1960s and 1970s, when most Jews had left the West Side, that secular Jewish agencies would actually fight against prejudice towards Mexican Americans, particularly in the schools.

Such motivations, however, did not diminish the fact that the ADL and the LHRC had improved conditions at Lake and other schools, chiefly through scientific surveys and joint observances of Christmas and Chanukah. But it is hard to deny that by the late 1950s Jews were beginning their exodus from the West Side, constructing the most powerful barrier of all between themselves and Mexican Americans-that of physical separateness and segregated neighborhoods. What had once only existed in the mind now became an unbridgeable reality.

57 The quoted phrase is from Leonard Dinnerstein, Uneasy at Home: Anti-Semitism and the American Jewish Experience (New York: Columbia University Press, 1987). 
Finally, this article has endeavored to go beyond the optimistic and triumphal tone of many historians in western American Jewish history, or American Jewish history for that matter, and inject an element of healthy skepticism - a skepticism of how truly "minimal" or relatively absent "overt" anti-Semitism was in the West; and a skepticism of how really self-assured western Jewish populations actually were. While this article has examined just one instance of Jewish insecurity, it suggests that certain aspects of Jewish life in the West were not that different from the crowded, contested and sometimes violent and cruel urban spaces of the East. ${ }^{58}$

58 Abrams, Jewish Women, 11, 181. Moses Rischin and John Livingston suggest the same in Jews of the American West. For interpretations of American Jewish history that examine themes of conflict, ambivalence and anxiety see Tony E. Michels, A Fire in Their Hearts: Yiddish Socialists in New York (Cambridge, MA: Harvard University Press, 2005); Eli Lederhendler, New York Jews and the Decline of Ethnicity 1950-1970 (Syracuse, New York: Syracuse State University Press, 2001); Lederhendler, "The New Filiopietism, or Toward a New History of Jewish Immigration to America," American Jewish History 93 (Mar. 2007): 120; Goldstein, The Price of Whiteness; and Gil Ribak, " "They are slitting the Throats of Jewish Children': The 1906 New York School Riots and Contending Images of Gentiles," American Jewish History 94 (Sept. 2008): 175-196. 